\title{
IDENTIFIKASI EKTOPARASIT PADA IKAN KOI (Cyprinus caprio)
}

\author{
Indra Priawan'), Endang Sulistyarini Gultom²), Ahmad Shafwan S. Pulungan²) \\ 1 Mahasiswa Program S1 Biologi,FMIPA, Universitas Negeri Medan \\ 2 Dosen Biologi, FMIPA, Universitas Negeri Medan \\ indrapriawan37@gmail.com
}

\begin{abstract}
Abstrak
Penelitian ini bertujuan untuk mengetahui ektoparasit yang terdapat pada ikan koi yang dijual di Jalan Bintang Medan. Ektoprarasit diketahui dapat menyebabkan penyakit pada ikan. Hal ini akan berdampak pada ikan lainnya. Kerusakan yang diakibatkan oleh ektoparasit ini akan meningkatkan intensitas penyakit pada ikan. Luka yang ditimbulkan oleh adanya ektoparasit pada ikan menjadi jalan masuk bagi kuman lain untuk menyerang ikan. Sampel yang digunakan ialah tiga ekor ikan koi yang mana ektoparasit yang menginfeksi ikan di amati lendir pada tubuh dan sirip ikan mas koki. Identifikasi ektoparasit dilakukan dengan menggunakan literatur. Ektoparasit yang teridentifikasi ialah Ichthyophthirius sp., Oodinium sp., Costia Sp. Dengan jumlah parasit terbanyak ialah spesies Oodinium sp.
\end{abstract}

Kata Kunci : Ektoparasit, ikan koi, identifikasi.

\section{Abstract}

This study aims to determine the ectoparasites found in koi fish sold in Jalan Bintang Medan. Ectoprarasites are known to cause disease in fish. This will have an impact on other fish. The damage caused by these ectoparasites will increase the intensity of disease in fish. The samples used are three koi fish which are ectoparasites that infect the fish in observing the mucus on the body and the chef's fin. The identified ectoparasites are Ichthyophthirius sp., Oodinium sp., Costia Sp. With the largest number of parasites is the species Oodinium sp.

Keywords : Ectoparasite, Koi fish, identification.

\section{Pendahuluan}

Ikan hias merupakan salah satu komoditas ekonomi yang potensial dan permintaannya setiap tahun kian meningkat. Ikan koi (Cyprinus carpio) merupakan salah satu jenis ikan hias yang mempunyai nilai ekonomi yang tinggi. Ikan koi atau disebut juga nishikigoi merupakan salah satu ikan hias yang banyak diminati. Hal ini dikarenakan ikan hias ini memiliki keindahan pada tubuhnya yaitu warna pada tubuhnya yang ber variasi dan juga ikan ini dipercaya mampu memberikan keberuntungan bagi siapapun yang memeliharanya (Twigg,2008).

Pasar ikan Jalan Bintang merupakan salah satu pasar ikan yang menjual ikan hias di kota Medan. Pasar ikan hias umumnya identik dengan tempat pemeliharaan / penampungan ikan yang terbatas, kepadatan ikan dalam aquarium yang cukup tinggi serta kuangnya perhatian terhadap kesehatan ikan dan kebersihan aquarium ikan yang dijual. Kepadatan ikan yang tinggi akan menyebabkan ikan menjadi stress dan hal ini menyebabkan ikan mudah terserang penyakit. Kualitas air yang buruk juga dapat memicu timbulnya parasit pada ikan (Handajani dan Widodo,2010). Menurut Rahayu dkk (2013) masalah utama yang sering dihadapi oleh para pembudidaya ikan diantaranya ialah penyakit pada ikan terutama parasit ikan.

Ikan yang terkena serangan parasit akan menyebabkan stres pada ikan. Hal ini berpengaruh pada mekanisme pertahanan tubuh pada ikan yang menjadi lemah dan menyebabkan ikan mudah terserang penyakit. Stress pada ikan juga dapat menyebabkan meningkatnya perkembangbiakan parasit sehingga akan membuat ikan menjadi semakin rentan akibat banyaknya parasit yang tumbuh pada ikan(Ramadan et al 2012) . Hal ini juga akan menyebabkan meningkatnya serangan parasit yang akan berdampak pada kesehatan ikan sehingga menyebabkan kerugian besar terhadap penjual ikan yang dikarenakan menurunnya mutu dan kualitas ikan (Syukran et al ,2017).

Serangan parasit dapat menyebabkan ikan kehilangan nafsu makan, kemudian akan menyebabkan ikan perlahan lahan menjadi lemas dan berakibat kematian pada ikan. Parasit pada ikan terbagi atas dua, yaitu ektoparasit dan endoparasit. Ektoparasit merupakan parasit yang hidup pada permukaan luar tubuh hospesnya. Endoparasit merupakan parasit yang hidup pada organ dalam tubuh hospesnya seperti hati, limfa, otak, sistem pencernaan, sirkulasi darah, rongga perut, otot daging, dan jaringan tubuh lainnya. 
Dampak negatif pada ikan hias akibat ektoparasit terlihat secara fisik (Purbomartono, 2010).

Konsumen pada umumnya tidak tahu dengan perawatan ikan sehingga ikan yang telah dibeli dari pasar ikan akan mengalami kematian pasca pembelian ikan dipasar ikan hias. Menurut Mulia (2010) Ektoparasit dapat mengakibatkan kematian akut atau tanpa menunjukkan gejala penyakit terlebih dahulu. Dampak negatif dari ikan hias akibat infeksi ektoparasit dapat terlihat secara fisik, hal ini dikarenakan ektoparasit terlihat jelas pada tubuh ikan (Purbomartono.2010). Ektoparasit dapat lebih mudah menular dakam usaha budidaya Cyprinus carpio. Infeksi ektoparasit umumnya menyebabkan kerusakan pada organ luar yaitu kulit dan insang. Kerusakan ini mengakibatkan timbulnya luka pada ikan. Kurangnya informasi mengenai jenis ektoparasit pada ikan koi di pasar ikan hias jalan Bintang, menjadi dasar untuk dilakukannya penelitian identifikasi ektoparasit pada ikan koi di pasar ikan hias jalan Bintang.

\section{Bahan Dan Metode}

\section{Bahan, Alat, dan Cara Kerja}

Alat dan bahan yang digunakan adalah cawan petri, scalpel, mikroskop, kaca objek, kaca penutup, ikan koi (Cyprinus carpio). Metode penelitian yang digunakan ialah metode observasi, ikan koi yang digunakan sebanyak 3 ekor yang di ambil dari pasar ikan hias jalan Bintang. Ikan yang telah di sediakan diambil lendir pada tubuh menggunakan scalpel. Lendir diambil dengan melakukan penggerukan dari kepala hingga ekor. Lendir yang didapatkan, kemudian diletakkan di atas gelas objek lalu ditutup dan diletakkan dibawah mikroskop lalu diamati. Dilakukan pengambilan dokumentasi untuk identifikasi ektoparasit menggunakan sumber literatur menurut Kabata (1985) yang didasarkan pada morfologi parasit yang ditemukan yang meliputi bentuk tubuh dan alat gerak.

\section{Hasil Dan Pembahasan}

Adapun parasit yang menginfeksi ikan mas koki ialah Ichthyophthirius sp., Oodinium sp., dan Costia Sp. (Gambar 1). Banyaknya spesies parasit yang ditemukan pada ikan koi menunjukkan bahwa ikan koi yang berasal dari pasar ikan hias jalan Bintang terkena serangan dari parasit. Dalam hal jumlah, parasit yang di temukan pada ikan koi bervariasi tiap spesiesnya. Hal ini menunjukkan bahwa kondisi akuarium dan kualitas air yang digunakan rendah. Menurut Effendy (1993) untuk pH yang ideal ialah 7,2-7,4 . Sehingga apabila tidak mencapai $\mathrm{pH}$ ideal dapat menjadi lingkungan yang cocok untuk pertumbuhan parasit pada ikan koi (Tabel 1).

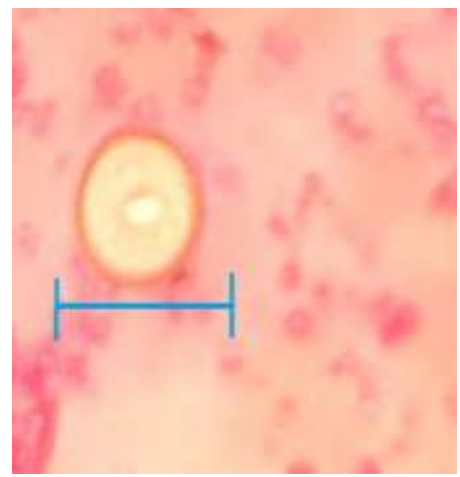

(1)

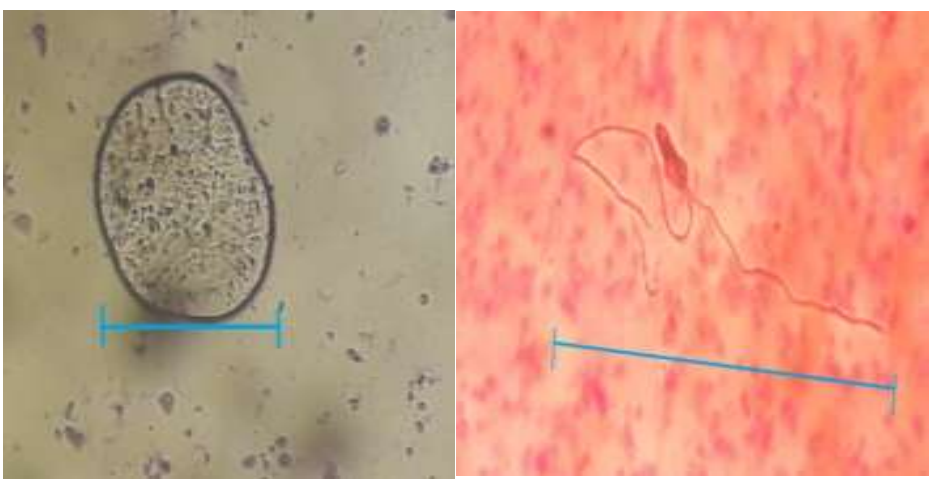

(2)
(3)

Gambar 1 Parasit yang ditemukan pada ikan mas koki : Ichthyophthirius sp.(1), Oodinium $s p(2)$, Costia Sp. (3)

Tabel 1. Jumlah ektoparasit yang ditemukan pada ketiga spesies ikan koi (Cyprinus carpio)

\begin{tabular}{|c|l|c|c|c|}
\hline \multirow{2}{*}{ No } & Ektoparasit & \multicolumn{3}{|c|}{ Parasit Yang Ditemukan Pada Ikan } \\
\cline { 3 - 4 } & & Ikan 1 & Ikan 2 & Ikan 3 \\
\hline 1 & Ichthyophthirius sp. & 1 & - & 2 \\
\hline 2 & Oodinium $s p$ & 2 & 2 & 3 \\
\hline 3 & Costia Sp. & - & - & 1 \\
\hline
\end{tabular}

Berdasarkan tabel 1 didapatkan bahwa tiga spesies ektoparasit yang ditemukan pada pengamatan yaitu Ichthyophthirius sp., Oodinium $s p$., dan Costia Sp. Ketiga ektoparasit ini tergolong dalam ektoparasit kelas protozoa. Parasit terbanyak ditemukan pada ikan ke-3. Dimana pada spesies ini di temukan 6 ektoparasit yang meliputi Ichthyophthirius sp., Oodinium sp., Costia Sp. dan di ikuti ikan ke-1 yang mana dtemukan sebanyak 3 ektoparasit meliputi yaitu Ichthyophthirius sp. dan 
Oodinium sp. Adapun spesies ektoparasit yang paling banyak ditemukan ialah Oodinium $s p$. yang ditemukan pada ketiga spesies ikan dengan jumlah 7 organisme yang ditemukan. Berdasarkan penelitian Sumiarti (2010) tingginya kehadiran Oodinium sp. ini diduga karena adanya pergantian musim sehingga kualitas air tidak stabil yang mengakibatkan ikan stress sehingga dengan mudah dapat di infeksi oleh parasit.

Parasit Ichthyophthirius sp. Merupakan parasit protozoa bercilia merupakan penyebab penyakit yang lebih dikenal dengan sebutan Ích'atau "white spot disease". Pada ikan yang dipakai, ditemukan adanya bintik putih pada bagian kepala, sirip ekor, dan badan dari ikan koi. Penyakit ini merupakan penyakit yang sering terjadi baik pada ikan hias maupun pada ikan konsumsi Floyd dan Peggy dalam Sumiarti dkk (2010). Parasit ini dapat bersifat mematikan benih ikan air tawar hingga 90\%. Infeksi berat dari parasit ini ialah pendarahan pada sirip ikan dan tubuh ikan akan tertutup lendir. Parasit ini akan meninggalkan hospesnya yang sudah mati dan akan berkembang biak membentuk kista pada substrat, sehingga berpotensi menginfeksi ikan lainnya (Purbamartono,2010).

Parasit Oodinium sp. Menyebabkan penyakit velvet merupakan ekroparasit yang menginveksi pada kulit dan insang ikan. Berdasarkan hasil pengamatan secara morfologi terhadap ikan, ikan koi yang dipakai memiliki beberapa area berwarna merah sebagai pertanda bahwa ikan terserang parasit ini dan adanya sisik yang terkelupas. Adapun akibat yang ditimbulkan oleh parasit ini ikan mengalami anoreksia, dan menyebabkan pendarahan pada insang. Gejala klinis pada Oodinium sp. dimulai dari sirip ikan, tahapan selanjutnya ikan akan terlihat seperti terkena taburan tepung. Pada tahapan berikutnya, potongan sisik atau kulit dari ikan akan terkelupas (Kabata,1985).

Parasit Costia sp. merupakan parasit yang menyebabkan pengelupasan sisik ikan (Sumiarti,2010). Hal ini sesuai dengan pengamatan yang dilakukan peneliti yaitu pada ikan ke-3 sisik ikan yang terkelupas pada beberapa area tubuhnya. Adapun penyakit yang ditimbulkan parasit ini menyebabkan sisik terangkat keatas dan akhirnya mengelupas. Pada awalnya penyakit ini hanya menyerang sisik ikan namun pada akhirnya akan merambat keseluruh tubuh ikan. Tumbuhnya parasit ini kemungkinan besar akibat lingkungan yang kurang baik dan tercemarnya air dalam kolam. Parasit ini umumnya menyerang ikan koi terutama famili Doitsu(Effendy,1993).

\section{Kesimpulan}

Berdasarkan penelitian diatas dapat disimpulkan bahwa parasit yang ditemukan pada ikan koi yang di jual di temoat penjualan ikan hias Jalan Bintang Medan ialah Ichthyophthirius sp., Oodinium sp., Costia sp. Dengan jumlah parasit terbanyak ialah spesies Oodinium sp. Berdasarkan ciri morfologi, ikan koi yang terserang parasit akan menunjukkan ciri-ciri memiliki area berwarna putih (White spot), sisik yang mengelupas, dan ada area yang berwarna merah hingga adanya beberapa bagian tubuh yang terlihat seperti tertutup tepung.

\section{Ucapan Terima Kasih}

Ucapan terima kasih penulis sampaikan kepada Ibu Endang Sulistyarini Gultom S.Si. Apt. M,Si. Selaku dosen Parasitologi dan juga kepada Bapak Ahmad Shafwan S. Pulungan S.pd., M.Si. Selaku dosen praktikum Parasitologi. Dan kepada pihak Laboratorium Biologi FMIPA UNIMED.

\section{Daftar Pustaka}

Effendy, Hersanto. 1993. Mengenal Beberapa Jenis Koi. Yogyakarta : Penerbit Kanisius.

Handajani , H dan Widodo W. 2010. Parasit dan Penyakit Ikan. Malabg : UMM Press.

Handayani,Retna, Y.T Adiputra, dan Wardiyanto. 2013. Identifikasi Dan Keragaman Parasit Pada Ikan Mas Koki (Carrasius auratus) Dan Ikan Mas (Cyprinus carpio) yang berasal dari lampung dan luar lampung. Jurnal Ilmu Perikanan Sumberdaya Perairan.

Kabata Z 1985. Parasites and Diseases of Fish Cultured in the Tropic. London : Taylor and Prancis

Mulia, D.S. 2010. Tingkat Infeksi Ektoparasit Protozoa pada Benih ikan Nila (Oreochromis niloticus) di Balai Benih ikan Pandak dan Sidobowa, Kabupaten Banyumas. Sains Akuatik. Vol 10 (1).

Purbomartono, C. 2010. Identify of Helminth and Crustacean Ectoparasites on Puntius javanicus fry at local hatchery center Sidabowa and Kutasari. Sains Akuatik. Vol.10 (2).

Rahayu, F. D., D. R. Ekastuti, R. Tiuria. 2013. Infestasi cacing parsitik pada insang ikan mujair (Oreochromis mossambicus). Acta Veterinaria Indonesia, 1(1):8-14.

Ramadan, A.R., N. Abdulgani. N. Triyani. 2012. Perbandingan prevalensi parasit pada insang dan usus ikan mujair (Oreochromis mossambicus) yang tertangkap di sungai aloo dan tambak kedung peluk, Kecamatan Tanggulangin, Sidoarjo. Jurnal Sains dan seni ITS, 1(1):E36 E39.

Sumiarti, Tuti dan Yani Aryati.2010. Penyakit Parasitik Pada Ikan Hias Air Tawar. 
Prosiding Forum Inovasi Teknologi Akuakultur.

Syukran,Muhammad, Sayyid Afdhal El Rahimi, dan Silvia Wijaya. 2017. Intensitas dan Prevalensi Ektoparasit Pada Ikan Cupang Hias (Betta splendens) di
PerairaanKabupaten Aceh Besar dan Kota Banda Aceh. Jurnal Ilmiah Mahasiswa Kelautan dan Perikanan Unsyiah. Volume 2 No.1.

Twigg,D. 2008. Buku Pintar Koi. Jakarta : Gramedia 